\title{
STRATEGY FOR DEVELOPMENT OF ORCHID ORNAMENTAL PLANT (Case Study of UPTD BBIH, Amoito Village, Ranomeeto District, South Konawe Regency)
}

\author{
Sri $^{\left.{ }^{*}\right)}$, Usman Rianse ${ }^{2)}$, Waode Yusria ${ }^{1)}$ \\ ${ }^{1}$ Department of Agribusiness Faculty of Agriculture, Universitas Halu Oleo Kendari 93232 \\ ${ }^{2}$ Department Agricultural Extension Faculty of Agriculture, Universitas Halu Oleo Kendari 93232
}

${ }^{*}$ Corresponding author: sripe49@gmail.com

To cite this article:

Sri, S., Rianse, U., \& Yusria, W. (2021). Strategy For Development of Orchid Ornamental Plant (Case Study of UPTD BBIH, Amoito Village, Ranomeeto District, South Konawe Regency). JIA (Jurnal IImiah Agribisnis) : Jurnal

Agribisnis dan IImu Sosial Ekonomi Pertanian, 6(4), 130 - 134. doi:http://dx.doi.org/10.37149/jia.v6i4.16034

Received: January 15, 2021; Accepted: August 31, 2021; Published: August 31, 2021

\begin{abstract}
This study aims to determine the strategy for developing ornamental orchids in UPTD BBIH, Amoito Village, Ranomeeto District, South Konawe Regency. This research is a case study on ornamental orchid plants determined on purpose (purposive sampling). Data analysis used the SWOT Analysis to determine the criteria and prospect alternatives that are the most priority for ornamental orchid plants. Based on the results of the identification of internal and external factors that determine the prospects for the development of ornamental orchids at UPTD BBIH, Amoito Village, Ranomeeto District, Konawe Selatan Regency, internal factors were found, namely the absence of technical guidance for workers, lack of service facilitation between product messages, using the availability of business capital and utilizing bonus purchase of ornamental plants orchids. While external factors are the lack of labor recruitment, the existence of a marketing network, using online media as promotion, and developing product creativity through exhibitions.
\end{abstract}

Keywords: development; orchids; ornamental; strategi

\section{INTRODUCTION}

The agricultural sector is one sector that has a massive role in contributing to Indonesia's development. Agriculture is a strategic sector that will continue to grow and develop as long as humans still need food, so the demand for food needs will continue to increase. In addition to meeting domestic food needs, agricultural products are also used as industrial raw materials. Agricultural development in Indonesia aims to increase agricultural production to meet domestic food and industrial markets, increase exports and farmers' incomes, expand job opportunities, and encourage equitable development (Adam \& Hermawan, 2011).

Horticultural development is one aspect of overall agricultural development. Horticultural studies are vegetables, fruits, and flowers, which have been developed and cultivated by many people as commercial plants that can benefit those who produce them. Horticultural commodities consisting of fruit plants, vegetables, ornamental plants, and medicinal plants are very prospective commodities to be developed considering the potential for natural resources, human resources, technology availability, and the increasing possibility for domestic and international market absorption (Zulkarnain., 2014)

Ornamental plants are one of the groups of plants in horticulture whose primary function is decoration. The decorative function is intended as a giver of beauty and attractiveness or can be enjoyed visually, whether planted in the yard or the room. So ornamental plants function to create beauty and magnificence in an object, having a beautiful shape and color. Ornamental plants can also provide a sense of economic value. This is because ornamental plant cultivation is an activity that requires a lot of labor, so ornamental plant cultivation is a provider of jobs. Ornamental plants also have a high selling value, so that they promise good profits and high economic yields. There are several results of ornamental plants that can be used as industrial raw materials in beauty and health. 
The economic meaning is also shown by the presence of several types of plants that generate foreign exchange for the country (Widyastuti, 2018)

One type of ornamental plant that some people use as one of their favorite plants is orchids. Orchid plants have good prospects because they have attractive beauty and high economic value, so many people plant and care for them. The orchid ornamental plant development program provides site-specific superior varieties coupled with seed propagation to obtain uniform plants, the application of BTS-based BOS, development of market-based production centers and regional potentials, improving the quality of human life resources, on-farm and off-farm institutional development in a cooperative pattern. and management cooperatives, development of networks and networks at home and abroad, development of orchid agribusiness business systems, compilation of orchid profile databases, and orchid promotion opportunities (Suryana, 2018)

Orchids are one of the most popular types of ornamental plants and are liked by many consumers because of their unique and attractive flower shapes and colors, durable and not easy to wither. This commodity can be used as ornamental garden plants, pots, and cuts. To produce good quality flowers need to be followed by excellent and correct cultivation procedures. Orchid flowers are one of the most widely used ornamental plants. It has become a part of modern civilization with flowers, causing orchids to increase along with the many important events, such as weddings, Eid, Christmas, New Year, and birthdays. Not to mention the need for flower bouquets, for congratulations, and table flower arrangements for hotels, restaurants, offices, and banks (Kuntoro et al., 2015)

One of the areas in Indonesia that have the potential to develop ornamental orchids is Southeast Sulawesi Province. Based on the data obtained, it is known that the harvested area and production of ornamental orchid plants have increased from 2016-2019. The display of ornamental orchids always shows a significant increase every year, while the harvested area in 2018 has decreased from 2017. However, the harvested area of ornamental orchids in Southeast Sulawesi Province increased in 2019 by $3915.00 \mathrm{~m}^{2}$. (BPS Southeast Sulawesi Province, 2020)

The production target of Orchid ornamental plants in Southeast Sulawesi Province shows that the overall target production of ornamental orchid plants in Southeast Sulawesi Province in 5 (five) years has increased every year. This can be indicated that the potential of ornamental orchid plants has a perfect opportunity to be developed (BPS Southeast Sulawesi Province, 2020)

Southeast Sulawesi has several districts, namely South Konawe Regency and South Konawe Regency, which have prospects for developing ornamental orchid plants. The following is data on the harvested area and production of ornamental orchids in South Konawe Regency, the harvested area of ornamental orchids was $325 \mathrm{~m}^{2}$ in 2018 and increased by $1803 \mathrm{~m}^{2}$ in 2019. Production of ornamental orchids in 2018 was 2285 stalks and expanded in 2018. in 2019 of 9727 stalks (BPS Southeast Sulawesi Province, 2020)

Ranomeeto is one of the sub-districts in the South Konawe Regency, which has prospects for developing ornamental orchid plants. Based on the data obtained, the harvested area of orchid ornamental plants in Ranomeeto District, the harvested area of ornamental orchid plants of $18 \mathrm{~m}^{2}$ increased by 360 in 2018 (BPS Regency South Konawe, 2020) Amoito Village is one of the villages that has an area of $2.17 \mathrm{~km}^{2}$ around $2.25 \%$ (BPS District Ranomeeo, 2018)

One of the business prospects for the development of ornamental orchids in Amoito Village is the UPTD BBIH (Regional Technical Implementation Unit of the Horticultural Seed Center) which functions as an Agrotourism and sales container to increase the potential of ornamental orchids, based on initial observations of the UPTD BBIH in which there are sales of ornamental plants, which has a planting area of $63 \mathrm{~m}^{2}$. Orchid ornamental plant business among various varieties, namely Dendrobium, Phalaenopsis, Gramophylum, Vanda, Oncidium, and Cattleya. The location is very far from urban areas, so processing sales in Amoito Village, Ranomeeto District, South Konawe Regency is complex. (Kuntoro et al., 2015) the development of an orchid plant business has good prospects for the community. (Gasnawati et al., 2021) The product of ornamental orchids is essential and deserves to be developed to see opportunities in improving ornamental orchids for the future. To make it happen, proper development is needed. The purpose of this study was to determine the Strategy for Developing Orchid Ornamental Plants Farming (Case Study of UPTD BBIH, Amoito Village, Ranomeeto District, South Konawe Regency).

\section{MATERIALS AND METHODS}

This research was conducted at UPTD Horticulture Seed Center on Jalan Sindang Kasih, Amoito Village, Ranomeeto District, South Konawe Regency. The location of the study was determined purposively, with the consideration that the site of the UPTD Center for Horticulture Seeds was selling orchids. This research was conducted in September-October 2020. This research is a 
case study on the prospect of developing ornamental orchids. Informants in this study were businessmen of ornamental orchids in UPTD BBIH, Amoito Village, Ranomeeto District, South Konawe Regency.

Analysis of the data used, namely SWOT analysis, aims to determine the internal and external environmental factors. That business performance can be determined by a combination of internal and external factors. Both of these factors should be considered in a SWOT analysis. SWOT analysis compares external factors, opportunities, threats, internal factors, strengths, and weaknesses (Rangkuti, 2008).

\section{RESULTS AND DISCUSSION}

\section{Internal Factors and External Factors}

Analysis of internal and external environmental factors of ornamental orchid plants following observations and interviews using a questionnaire. Identification of business ecological factors is carried out to formulate an alternative prospect for developing ornamental orchids that will be applied at UPTD BBIH, Amoito Village, Ranomeeto District, South Konawe Regency.

Table 1. The results of the analysis of internal environmental factors (IFAS).

\begin{tabular}{|c|c|c|c|c|}
\hline No & Strength & Weight (B) & Rating $(\mathrm{R})$ & Score $(B \times R)$ \\
\hline 1 & $\begin{array}{l}\text { Availability of business capital for ornamental } \\
\text { orchids }\end{array}$ & 0,20 & 4 & 0,8 \\
\hline 2 & Bonus for purchasing orchids & 0,15 & 4 & 0,6 \\
\hline \multirow[t]{3}{*}{3} & Orchid ornamental plant seed quality & 0,10 & 4 & 0,4 \\
\hline & Sub Quantity & 0,45 & & 1,8 \\
\hline & Weakness & & & \\
\hline 1 & Lack of product delivery service facilitation & 0,20 & 1 & 0,2 \\
\hline 2 & Lack of technical guidance for workers & 0,25 & 1 & 0,25 \\
\hline \multirow[t]{3}{*}{3} & $\begin{array}{l}\text { Instability of the level of sales of ornamental } \\
\text { orchids }\end{array}$ & 0,10 & 2 & 0,2 \\
\hline & Sub quantity & 0,55 & 16 & 0,65 \\
\hline & Total & 1,00 & & 2,45 \\
\hline
\end{tabular}

Source: Primary Data Processed, 2020

Based on Table 1, it can be seen that the strength factor is more significant with a value of (1.8) compared to the weakness factor of (0.65). Thus the total aspect of IFAS (Strengths and Weaknesses) for the development of ornamental orchids is (2.45). However, internal factors need to be improved again to eliminate the weaknesses of the business and then maximize profits and minimize existing inadequacies. Opportunities and threats include external business conditions in developing ornamental orchid plants in UPTD BBIH, Amoito Village, Ranomeeto District, South Konawe Regency.

Table 2. Results of analysis of external environmental factors (EFAS).

\begin{tabular}{|c|c|c|c|c|}
\hline No & Opportunity & Weight (B) & Rating (R) & Score $(B \times R)$ \\
\hline 1 & Availability of online media as promotion & 0,25 & 4 & 1,0 \\
\hline 2 & Increase product creativity through exhibitions & 0,15 & 4 & 0,6 \\
\hline 3 & There is marketing distribution & 0,15 & 4 & 0,6 \\
\hline & Sub Quantity & 0,55 & & 2,2 \\
\hline \multicolumn{5}{|c|}{ Threat } \\
\hline 1 & Lack of labor recruitment & 0,20 & 1 & 0,20 \\
\hline 2 & There are limitations of the marketing network & 0,15 & 1 & 0,15 \\
\hline \multirow[t]{3}{*}{3} & $\begin{array}{l}\text { There are competitors of imported orchid } \\
\text { varieties }\end{array}$ & 0,10 & 4 & 0,4 \\
\hline & Sub quantity & 0,45 & 18 & 0,75 \\
\hline & Total & 1,00 & & 2,95 \\
\hline
\end{tabular}

Source: Primary Data Processed, 2020

Based on Table 2, it can be seen that the opportunity factor is more significant with a value of (2.2) than the threat factor of (0.75). Thus the total value of the EFAS factor in the development of ornamental orchid plants is $(2.95)$ 


\section{Grand Strategy Matrix}

The determination of strategy using the Grand Strategy matrix is used to see the coordinates carried out using the internal and external factors quadrant. To find the coordinates of the point, it can be searched in the following way:

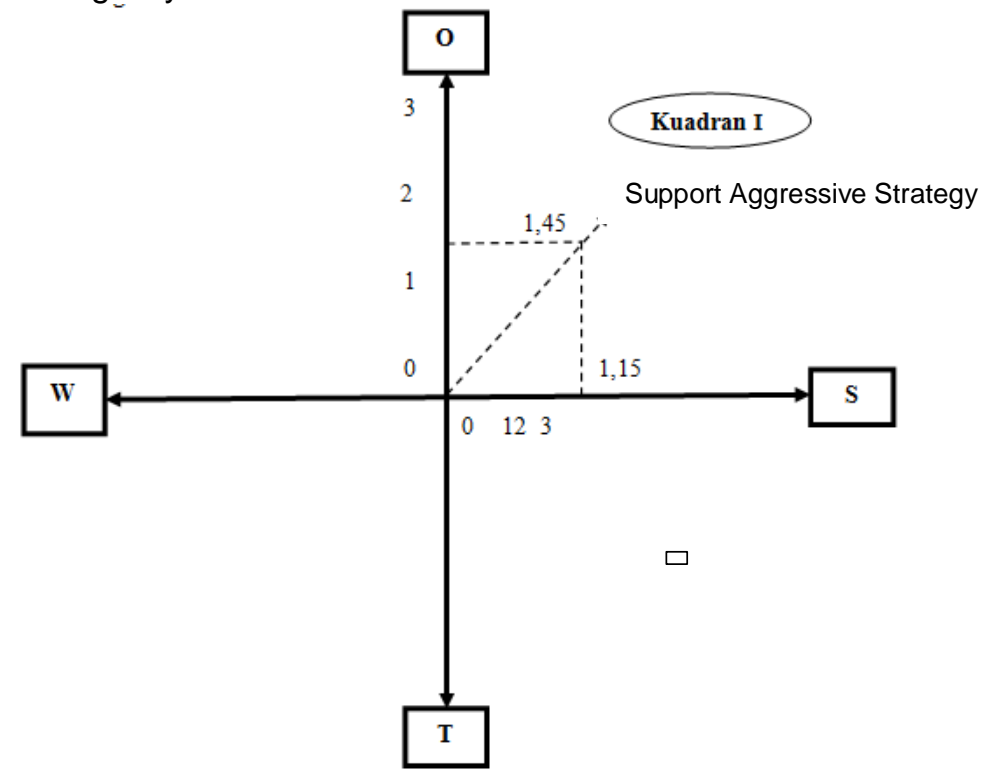

Figure 1. BBIH UPTD Position in the Grand Strategy Matrix

Coordinates of Internal Factors (Total Strength Score-Total Weakness Score) $=1.8-0.65=$ 1.15. Coordinates of External Factors (Total Opportunity Score - Total Threat Score) $=2.2-0.75=$ 1.45 so that the coordinate point is (1.15: 1.45) (Wiyono et al., 2019). The development strategy implemented by UPTD BBIH can be seen in Table 3

Table 3. UPTD BBIH SWOT Matrix for ornamental orchids

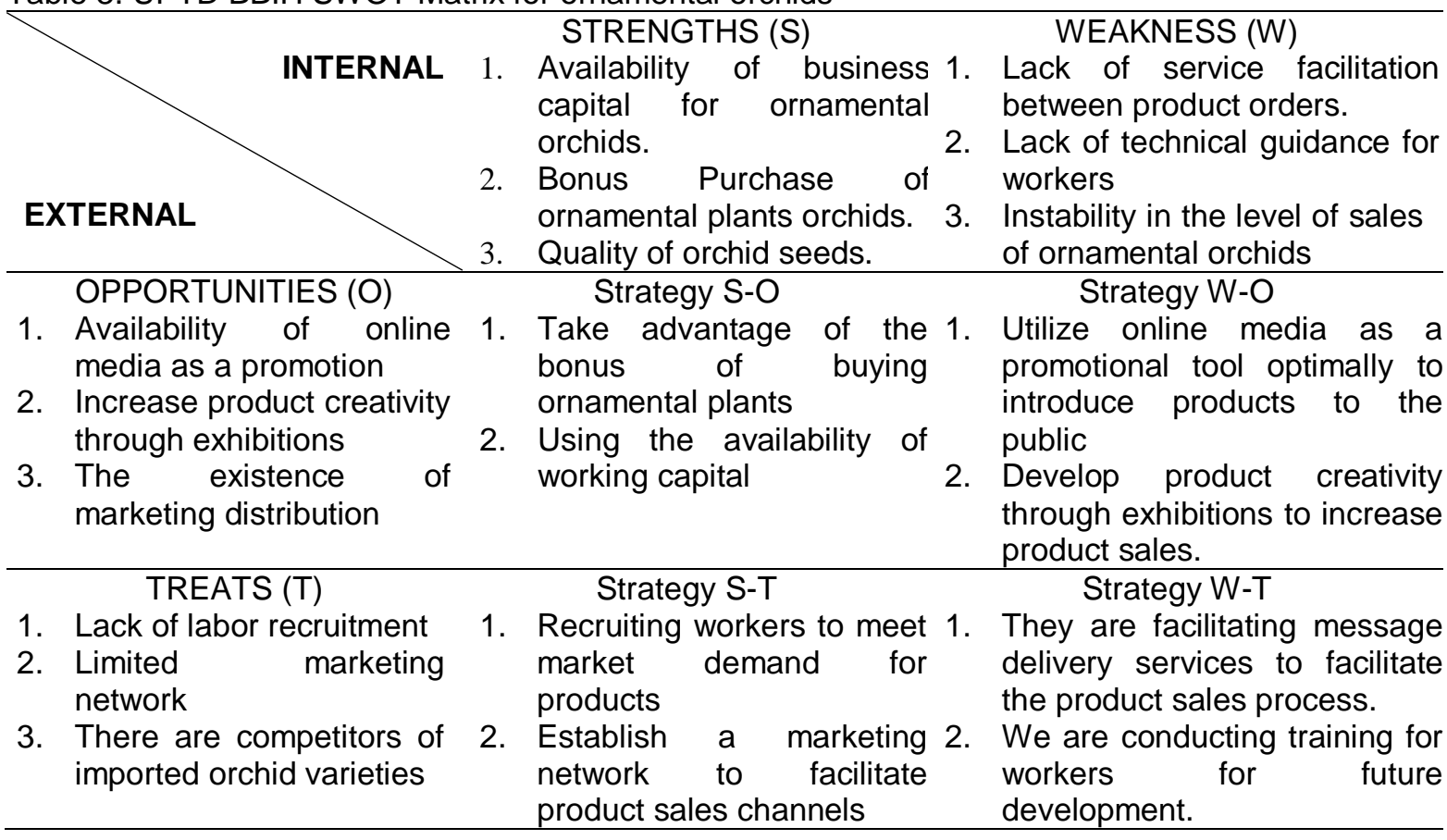

The SWOT matrix is a systematic identification of various factors to formulate a strategy. Based on the weighting and rating of internal and external factors, in Table 3 , the value of internal factors obtained is smaller with a value of (1.15) than the value of external factors of (1.45). Illustrates that the elements consisting of opportunities and threats by UPTD BBIH have a significant role in 
developing ornamental orchid plants, namely in making decisions to determine the strategy that orchid ornamental plant business actors will use. The results of the analysis of internal strategy and external factors are described in the IFAS and EFAS tables. Several approaches can be drawn up by orchid ornamental plant business actors through giving bonuses, developing marketing collaborations by facilitating message delivery services (online), recruiting workers, and conducting training for workers as stated by (Santayana et al., 2017; Syahroni et al., 2019)

\section{CONCLUSIONS AND SUGGESTIONS}

Based on the results of the identification of internal and external factors that determine the prospects for the development of ornamental orchids at UPTD BBIH, Amoito Village, Ranomeeto District, Konawe Selatan Regency, internal factors were found, namely the absence of technical guidance for workers, lack of service facilitation between product messages, using the availability of business capital and utilizing bonus purchase of ornamental plants orchids. While external factors are the lack of labor recruitment, the existence of a marketing network, using online media as promotion, and developing product creativity through exhibitions.

\section{REFERENCE}

Adam, L., \& Hermawan, I. (2011). Pengaruh Aspek Fiskal Dan Moneter Terhadap Pdb Sektor Pertanian. Jurnal Ekonomi Dan Kebijakan Publik, 2(1), 459-494. https://doi.org/https://doi.org/10.22212/jekp.v2i1.98

BPS Kabupaten Konawe Selatan. (2020). Kabupaten Konawe Selatan dalam Angka 2020. BPS Kabupaten Konawe Selatan.

BPS Kecamatan Ranomeeo. (2018). Kecamatan Ranomeetp Dalam Angka 2017. BPS Kecamatan Ranomeeto.

BPS Provinsi Sulawesi Tenggara. (2020). Provinsi Sulawesi Tenggara Dalam Angka 2020. Badan Pusat Statistik Provinsi Sulawesi Tenggara.

Gasnawati, R. A., Abdi, \& Hamzah, A. (2021). Sensitivity Analysis of Decorative Plant Business in Kendari City (Case Study on Dahlia Ornamental Plant Business). International Journal of Agricultural Social Economics and Rural Development (ljaserd), 1(1), 13-16. https://doi.org/http://dx.doi.org/10.37149/ijaserd.v1i1.14159

Kuntoro, B. A., J.F, W., \& Tumbuan, A. (2015). Potensi Pengembangan Agribisnis Bunga Anggrek Di Kota Batu Jawa Timur. Jurnal LPPM Bidang Ekososbudkum, 2(1).

Rangkuti, F. (2008). Analisis Swot Teknik Membedah Kasus Bisnis. PT Gramedia Pustaka Utama.

Santayana, Setiadi, A., \& DP, E. (2017). Strategi Pengembangan Agribisnis Tanaman Anggrek Di Kota Semarang. Agromedia, 35(2), 1-9.

Suryana, A. (2018). Prospek dan Arah Pengembangan Agribisnis Anggrek. Badan Penelitian dan Pengembangan Pertanian, Departeman Pertanian.

Syahroni, Surni, \& Dirgantoro, M. A. (2019). Hubungan antara Bauran Pemasaran dengan Penerimaan dari Tanaman Hias di Kota Kendari. JIA (Jurnal Ilmiah Agribisnis): Jurnal Agribisnis Dan IImu Sosial Ekonomi Pertanian, 4(5), 136-141. https://doi.org/http://dx.doi.org/10.33772/jia.v4i5.7918

Widyastuti, T. (2018). Teknologi Budidaya Tanaman Hias Agribisnis. CV Mine.

Wiyono, G., Welsa, H., \& Prayekti, P. (2019). Analisis SWOT Dan AHP Sebagai Acuan Strategi Optimasi Student Body. Jurnal Riset Bisnis Dan Manajemen, 12(1), 1. https://doi.org/10.23969/jrbm.v12i1.950

Zulkarnain. (2014). Dasar-Dasar Hortikultura. PT Bumi Aksara. 